\title{
HIGHER EDUCATION AND BUSINESS STANDARDS
}





\section{HIGHER EDUCATION A ND \\ BUSINESS STANDARDS}

BY

\section{WILLARD EUGENE HOTCHKISS}

DIRECTOR OF BUSINESS EDUCATION

AT THE UNIVERSITY OF MINNESOTA

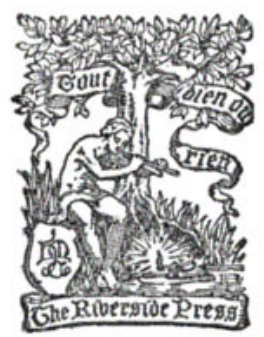

BOSTON AND NEW YORK

HOUGHTON MIFFLIN COMPANY

Cbe fibergioe pres Cambrioge

I 918 
COPYRIGHT, 1918, BY THE REGENTS OF THE UNTVERSTTY OF CALIFORNIA

ALL RIOKTS RESERVED

Pwblished March ror8 


\section{BARBARA WEINSTOCK LECTURES ON THE MORALS OF TRADE}

This series will contain essays by representative scholars and men of affairs dealing with the various phases of the moral law in its bearing on business life under the new economic order, first delivered at the University of California on the Weinstock foundation. 
